\title{
TINJAUAN HUKUM DAN IMPLEMENTASI PEMUTAKHIRAN KARTU KELUARGA DALAM MEUWUJUDKAN KETUNGGALAN IDENTITAS DI KABUPATEN GRESIK
}

\author{
Nurul Puspita Wardani \\ nurul.puspita.wardani-2016@pasca.unair.ac.id \\ Sains Hukum dan Pembangunan Sekolah Pascasarjana UNAIR \\ Jln. Airlangga No.4-6 Surabaya
}

\begin{abstract}
In 2008, the Ministry of Home Affairs recorded the Electronic Population Identity Card (e-KTP) with the main objective of establishing an orderly population administration through the issuance of 1 (one) Population Registration Number (NIK) for 1 (one) resident. The issuance of NIK-based national ID cards is supported by building accurate population databases at the Regency / City, Provincial and Central levels which are connected online using the Population Administration Information System (SIAK). High population mobility experienced by Gresik as one of the bases of the East Java and Surabaya suburban industries and other metropolitan cities is strongly influenced by the behavior of the people with the tendency of residents to approach work sites but there is no desire to settle in the area of work or population movements in time short between the workplace and his residence. the formulation of the problems discussed are as follows, first, what is the legal review of laws and regulations governing population administration and civil records to provide a normative basis for the implementation of family card updates; population. The approach used in this study is the socio-legal approach. The Innovation of My Family Card Re-Data (Kakek Ku Datang) The Civil Registry Population Office of Gresik Regency is a solution to establish an orderly population administration in Gresik. The Kakek Ku Datang program is one of the best practices in reviving local resources at the village level to support the implementation of services or regional development programs, as well as being an example of responsive services to the community supported by an interactive system that provides communication space for the public through application and socialization media.
\end{abstract}

Keywords: Family Card; Kakek Ku Datang; Civil Registry.

\section{A. Pendahuluan}

Pada Tahun 2008, Kementerian Dalam Negeri melakukan perekaman Kartu Tanda Penduduk elektronik (e-KTP) dengan tujuan utama untuk membangun tertib administrasi kependudukan melalui penerbitan 1 (satu) Nomor Induk Kependudukan (NIK) untuk 1 (satu) orang penduduk. Penerbitan KTP berbasis NIK secara Nasional didukung dengan membangun database kependudukan yang akurat di tingkat Kabupaten/Kota, Provinsi, dan Pusat yang terkoneksi secara online menggunakan Sistem Informasi Administrasi Kependudukan (SIAK). Berjalannya proses perekaman e-KTP hingga Tahun 2014 di Kabupaten Gresik ditemukan pelbagai permasalahan yaitu;

a.Tercatat Data Ganda sebanyak 23.765 jiwa. Hal ini berarti terdapat seorang penduduk yang memiliki identitas kependudukan NIK dan/atau KTP dengan NIK berbeda dan/atau terdaftar pada Kartu Keluarga (KK) lebih dari 1 (satu) identitas baik dalam lingkup 1 (satu) desa maupun lintas desa, kecamatan, kabupaten/kota, hingga provinsi. 
b.Tercatat Data Anomali sebanyak 69.230 jiwa. Data anomaly sebagaimana dimaksud adalah data kependudukan yang diragukan dalam SIAK. Identitas penduduk yang tercatat dalam Data anomali adalah penduduk yang belum pernah melakukan perekaman e-KTP, penyimpangan substansial atau atribut data yang tidak sesuai dengan data base SIAK kesalahan entry dan pelbagai faktor lainnya.

c.Selain itu, dari jumlah penduduk usia 0-18 tahun yang terdaftar masih tercatat 58,7\% yang telah memiliki akta kelahiran atau masih dibawah target pencapaian nasional sebesar $75 \%$ pada tahun 2015 .

Pelbagai permasalahan sebagaimana telaah di atas menghadirkan Jurang Pemisah dalam upaya untuk mewujudkan tertib administrasi kependudukan. Alternatif terbaik dalam menyelesaikan permasalahan ini adalah memperbaiki atribusi Kartu Keluarga (KK) yang notabene mencakup identitas terlengkap penduduk dalam lingkup keluarga meliputi nama, NIK, jenis kelamin, tanggal lahir, agama, jenis pekerjaan, status perkawinan, status hubungan dalam keluarga, kewarganegaraan, hingga nama ayah dan ibu. Perbaikan kualitas KK dipilih sebagai alternatif terbaik karena komprehensifitas data kependudukan yang dimuatnya maka KK dapat dianggap sebagai "Jembatan" untuk menyeberangi jurang pemisah tersebut.

Pada kenyataannya, dari 1.316.143 Jiwa penduduk Kabupaten Gresik per Desember Tahun 2014 terdapat 369.120 Keluarga yang keseluruhannya telah memiliki KK akan tetapi tercatat 256.047 KK atau mencapai 69,37\% yang dikategorikan sebagai Count 0 dengan artian tidak pernah diperbarui sejak diterbitkan pada tahun 2008. Stagnasi terhadap updating KK selama lebih dari 6 (enam) tahun, 2008 s.d. 2014, sangat bertolak belakang terhadap Perubahan Status Penduduk yang dinamis. Padahal, secara normatif telah diatur bahwa perubahan data dalam keluarga akibat peristiwa kelahiran, kematian, kepindahan, dll wajib dilaporkan oleh Kepala Keluarga kepada Desa/Kelurahan selambat-lambatnya 14 hari kerja.

Stagnasi data keluarga atau KK count 0 sangat berpengaruh terhadap kelompok miskin, buta huruf, penyandang cacat,lansia, imigran, perempuan, pemuda, minoritas etnis,dan pelbagai kelompok lainnya. Telaah pengaruh tersebut antara lain;

a.Menimbulkan potensi ganda, palsu, dan pelbagai permasalahan data pemilih yang dirilis oleh KPU dalam penyelenggaran pemilihan umum;

b.Korelasi terhadap Data PPLS 2011sebanyak 97.426 keluarga miskin sebagai basis anggaran penanggulangan kemiskinan dari APBD Kabupaten Gresik pada tahun 2014 sebesar 6\% atau sekitar 133,8 Milyar dapat dipastikan belum optimal mengingat sasaran program ditujukan by name by addres sedangkan 69,37\% data keluarga secara keseluruhan masih belum diperbarui; 
c.Pemutakhiran biodata penduduk berdasarkan NIK bekorelasi dengan tabel catatan sipil kelahiran dan kematian dalam SIAK;

d.Secara sistemik dapat menghambat penyelenggaraan pelayanan publik dan pencapaian pembangunan Daerah mengingat penduduk telah dimaknai sebagai subyek dan obyek pembangunan.

Berkenaan dalam pelayanan publik untuk menjamin keterpenuhan identitas hukum dan administrasi kependudukan sebagaimana diamanatkan dalam Peraturan Pemerintah No. 2 Tahun 2015 dalam Strategi Pembangunan Lintas Sektoral Penanggulangan Kemiskinan dalam Buku II Agenda Pembangunan Bidang RPJMN 2014-2019 bahwa penanggulangan kemiskinan dicapai melalui perluasan dan peningkatan pelayanan dasar bagi masyarakat kurang mampu. Perluasan penjangkauan dalam penyediaan layanan publik terutama diarahkan pada Paket Pelayanan Dasar Minimal yaitu administrasi kependudukan, kesehatan, pendidikan, perlindungan sosial, dan infrastruktur dasar (perumahan yang layak, akses terhadap listrik, air minum, sanitasi, transportasi dan telekomunikasi). Peningkatan dan perluasan pelayanan dasar tersebut dilaksanakan dengan memperkuat koordinasi perencanaan dan pelaksanaan program dan sektor terkait sehingga memfokuskan kepada sasaran dan target yang sama.

Selaras dengan rumusan rencana strategis nasional maka dirumuskan Integrated Development Planning yang dimuat dalam Peraturan Daerah Nomor 09 Tahun 2016 tentang RPJMD Kabupaten Gresik Tahun 2016-2021 dalam hal penanggulangan kemiskinan melalui penguatan peran lintas sektoral untuk menghadirkan kebijakan yang nyata di 4 (empat) dimensi kemiskinan yaitu meningkatkan keberdayaan kesehatan; pendidikan; ekonomi dan ketenagakerjaan; dan infratstruktur dasar.

Pada kenyataannya, program perlindungan sosial dalam penanggulangan kemiskinan bahkan program pembangunan lainnya masih belum sepenuhnya meletakkan "manusia Gresik" sebagai subyek dan obyek seutuhnya dalam pembangunan. Bukti konkret dalam permasalahan fundamental ini adalah korelasi anggaran kemiskinan Kabupaten Gresik selama 2011-2015 mencapai Rp.938,554,200,789.86 atau 938,5 Milyar dengan Komposisi APBN sebesar Rp.616,603,963,984.60 (66\%); APBD Prov Jatim Rp.21,519,074,647.69 (2\%); dan APBD Kab. Gresik Rp.300,431,162,157.57 (32\%) namun hanya mampu menurunkan tingkat kemiskinan sebesar 1.92 poin, dari tahun 2011 sebesar 15,33\% menjadi 13,41\% pada tahun 2014. Dengan artian bahwa jumlah penduduk miskin sebanyak 181.700 jiwa pada tahun 2011 menurun 14.750 jiwa hingga menjadi 166,950.00 jiwa pada tahun 2014. Hal ini berarti bahwa setiap perubahan status 1 (satu) jiwa penduduk miskin membutuhkan dana mencapai Rp63,630,793.27 selama 4 (empat) tahun. 
Ketidakefektifan capaian kinerja program perlindungan sosial sebagaimana dijabarkan di atas disebabkan oleh;

1.konsep program yang cenderung karitatif (belas kasih) seperti santunan atau bantuan sosial seremonial disebabkan ketidakpahaman satuan kerja atau stake holder penanggulangan kemiskinan memahami kearateristik kemiskinan yang dihadapi;

2.ketidak tepat sasaran penerima manfaat program perlindungan sosial; tidak adanya basis data yang mengukur perubahan status kesejahteraan penduduk miskin;

3.Ketidakvalidan data penerima bantuan yang berbasis proxy atau survey based.

Berdasarkan telaah di atas, diperoleh intersection point yaitu konsep fundamental untuk membangun manusia dalam pembangunan dengan artian bahwa program perlindungan sosial seharusnya meletakkan penduduk sebagai penerima manfaat secara tepat, terukur, dan dapat diketahui proses perubahan status kesejahteraannya sehingga dapat menjadi landasan evaluasi keberhasilan program secara berkelanjutan. Selaras dengan telaah tersebut, maka pemutkahiran kartu keluarga dapat mewujudkan data kependudukan yang "bersih" dengan artian valid, terupdate, unik, dan integrative. Data kependudukan yang dimutakhirkan menjadi alternatif strategis untuk mengarahkan implementasi program-program pembangunan daerah agar tetap sasaran dan akuntabel. Hal ini sesuai dengan konsep Ketunggalan identitas dalam Pasal 1 Undang-Undang Republik Indonesia Nomor 24 Tahun 2013 Tentang Perubahan Atas Undang-Undang Nomor 23 Tahun 2006 Tentang Administrasi Kependudukan bahwa Nomor Induk Kependudukan (NIK) adalah nomor identitas Penduduk yang bersifat unik atau khas, tunggal dan melekat pada seseorang yang terdaftar sebagai Penduduk Indonesia.

Berlandaskan latarbelakang tersebut diatas, maka rumusan masalah yang dibahas adalah sebagai berikut :

1.Bagaimanakah tinjauan hukum peraturan perundang-undangan yang mengatur tentang administrasi kependudukan dan catatan sipil guna memberikan landasan normatif pelaksanaan pemutakhiran kartu keluarga?

2.Bagaimanakah implementasi pemutakhiran kartu keluarga diKabupaten Gresik dan pengaruhnya terhadap inovasi kependudukan sertapemanfaatan data kependudukan?

\section{B. Metode}

Pendekatan yang digunakan dalam penelitian ini adalah pendekatan sosio-legal merupakan kombinasi antara pendekatan yang berada dalam rumpun ilmu- ilmu sosial, termasuk di dalamnya ilmu politik, ekonomi, budaya, sejarah, antropologi, komunikasi dan sejumlah ilmu lainnya, yang dikombinasikan dengan pendekatan yang dikenal dalam ilmu hukum, seperti pembelajaran mengenai asas-asas, doktrin dan hirarki perundang-undangan. Pendekatan sosio-legal dengan 
demikian, menjadi konsep tunggal atas kombinasi tersebut. Lebih lanjut Abdulkadir Penelitian hukum empiris menggunakan studi kasus hukum empiris berupa perilaku hukum masyarakat dengan pokok kajian adalah hukum yang dikonsepkan sebagai perilaku nya (actual behavior) sebagai gejala sosial yang bersfifat tidak tertulis. ${ }^{1}$

\section{Pembahasan}

\section{Tinjauan Hukum Pelaksanaan Pemutakhiran Kartu Keluarga}

Administrasi kependudukan adalah $^{2}$ rangkaian kegiatan penataan dan penertiban dalam penerbitan dokumen dan data kependudukan melalui pendaftaran penduduk, pencatatan sipil,

\footnotetext{
${ }^{1}$ Abdulkadir Muhammad, (2005). Hukum dan Penelitian Hukum. Bandung : PT citra Aditya Bhakti,h.41

${ }^{2}$ Ridwan, H.R. (2014). Hukum Administrasi Negara. Jakarta: RajaGrafindo Persada Jakarta, h.37
} 
pengelolaan informasi kependudukan serta pendayagunaan hasilnya untuk pelayanan publik dan pembangunan sektor lain. Dokumen kependudukan adalah dokumen resmi yang diterbitkan oleh instansi pelaksana yang mempunyai kekuatan hukum sebagai alat bukti autentik yang dihasilkan dari pelayanan pendaftaran penduduk dan pencatatan sipil. Dokumen kependudukan pada dasarnya meliputi: Biodata Penduduk, Kartu Keluarga (KK), Kartu Tanda Penduduk (KTP), Surat Keterangan Kependudukan dan Akta Pencatatan Sipil.

Penyelenggaran administrasi kependudukan yang telah dilakukan pemerintah selama ini antara lain didasarkan pada Keppres No. 52 Tahun 1977 tentang pendaftaran penduduk dengan pedoman pelaksanaannya adalah Permendagri No. 8 Tahun 1977. Acuan lainnya adalah UU No. 10 Tahun 1992 tentang perkembangan kependudukan dan pembangunan keluarga sejahtera. Dalam pasal 8 ayat 3 dari UU tersebut ditegaskan pentingnya penyelenggaraan pencatatan kejadian vital (kelahiran, kematian, pindah, dsb) yang dialami penduduk sebagai sarana memantau perkembangan, keselarasan dan keseimbangan penduduk yang diukur dari kualitas diri dan kualitas lingkungan hidup penduduk. ${ }^{3}$ Dasar lainnya adalah PP No. 27 Tahun 1994 tentang pengelolaan perkembangan kependudukan dimana dinyatakan bahwa penyelenggaraan sistem informasi perkembangan kependudukan diperlukan dalam mendukung perumusan kebijakan pembangunan dan lingkungan hidup. (Sadono, 2008) Aturan yang dianut dalam Administrasi Kependudukan adalah UU No 23 Tahun 2006 tentang Administrasi Kependudukan dan PP No 37 tahun 2007 tentang UU No 23 tahun 2006 tentang administrasi kependudukan. Beberapa aturan yang dianut dalam prototype SIAK BDT adalah sebagai berikut: (Rohman, 2008)

a.Setiap penduduk memiliki NIK yang bersifat unik dan khas. (UU No 23 Tahun 2006 Pasal 1) b.NIK berlaku seumur hidup dan selamanya, tidak berubah dan tidak mengikuti perubahan domisili. (PP No 37 Tahun 2007 Pasal 38)

c.Penduduk Warga Negara Indonesia dan Orang Asing yang memiliki Izin Tinggal Tetap hanya diperbolehkan terdaftar dalam 1 (satu) KK. (UU No 23 Tahun 2006 Pasal 62 ayat 1) d.Nomor KK berlaku untuk selamanya. Nomor KK baru akan diterbitkan jika terjadi perubahan kepala keluarga. (UU No 23 Tahun 2006 Pasal 61 ayat 3)

e.Sebuah Kartu Keluarga (KK) wajib memiliki kepala keluarga (minimal satu anggota yakni kepala keluarga itu sendiri) (Penjelasan UU No 23 Tahun 2006 Pasal 61 ayat 1)

f. Perubahan susunan keluarga dalam KK adalah perubahan yang diakibatkan adanya peristiwa kependudukan atau peristiwa penting seperti pindah datang, kelahiran, atau

\footnotetext{
${ }^{3}$ Nurmayani. (2009). Hukum Administrasi Daerah. Bandar Lampung: Universitas Lampung, h. 21.
} 
kematian. (Penjelasan UU No 23 Tahun 2006 Pasal 62 ayat 2)

g.Penduduk yang meninggal dan pindah akan kehilangan keanggotaan KK di KK asal atau lama.

h.Penduduk datang dapat didaftarkan pada KK lama atau membuat KK baru pada tempat tujuan datang.

Meskipun telah dikeluarkan berbagai peraturan yang mengatur perlunya tertib administrasi kependudukan menemukan bahwa upaya-upaya mengintensifkan pelaksanaan pendaftaran penduduk sebagai sarana menertibkan administrasi penduduk guna memantau perkembangan kependudukan masih jauh dari harapan. ${ }^{4}$

\section{Implementasi Pemutakhiran Kartu Keluarga Di Kabupaten Gresik}

Perbaikan data Kartu Keluarga sebagai titik temu untuk mengatasi permasalahan Data Ganda dan Data Anomali pertama kali dilakukan oleh Dinas Kependudukan Catatan Sipil (Dispendukcapil) Kabupaten Gresik dengan mencetak keseluruhan salinan KK kategori Count 0 sebanyak 256.047 KK. Selanjutnya, KK tersebut dibagikan kepada Kasi Kecamatan untuk dilakukan pendataan ulang. Namun, pendataan ulang dengan metode ini sangat mengecewakan karena feedback yang diharapkan sangat kecil dengan artian bahwa dari sekian ribu lembar KK Count $\mathrm{O}$ yang telah dibagikan hanya segelintir yang disetor kembali dengan perbaikan termuthakir ke Dispendukcapil. Stagnasi data keluarga atau KK count 0 sangat berpengaruh terhadap kelompok miskin, buta huruf, penyandang cacat,lansia, imigran, perempuan, pemuda, minoritas etnis, dan pelbagai kelompok lainnya. Telaah pengaruh tersebut antara lain;

a.Menimbulkan potensi ganda, palsu, dan pelbagai permasalahan data pemilih yang dirilis oleh KPU dalam penyelenggaran pemilihan umum;

b.Korelasi terhadap Data PPLS 2011sebanyak97.426 keluarga miskin sebagai basis anggaran penanggulangan kemiskinan dari APBD Kabupaten Gresik pada tahun 2014 sebesar $6 \%$ atau sekitar 133,8 Milyar dapat dipastikan belum optimal mengingat sasaran program ditujukan by name by addres sedangkan $69,37 \%$ data keluarga secara keseluruhan masih belum diperbarui;

c.Pemutakhiran biodata penduduk berdasarkan NIK bekorelasi dengan tabel catatan sipil kelahiran dan kematian dalam SIAK;

d.Secara sistemik dapat menghambat penyelenggaraan pelayanan publik dan pencapaian pembangunan Daerah mengingat penduduk telah dimaknai sebagai subyek dan obyek pembangunan. 
${ }^{4}$ Harbani Pasolong. (2010). Teori Administrasi Publik. Alfabeta: Bandung., h.14. 
Belajar dari pengalaman tersebut, Dispendukcapil meluncurkan Program Kakekku Datang yang merupakan kepanjangan dari “Kartu Keluarga Ku Data Ulang”. Melalui program ini, Pemerintah Kabupaten Gresik berupaya menghadirkan pelayanan administrasi kependudukan yang inklusif, integratif, dan responsif di tengah masyarakat.

Kakekku Datang merupakan inovasi dalam penyelenggaraan pelayananan administrasi kependudukan melalui validasi data kependudukan berbasis Count 0 dengan 5 (lima) paket pelayanan. Pelayanan Kakekku Datang dilaksanakan secara inklusif dengan melibatkan 8000 pengurus RTRW dibawah rentang kendali 356 petugas register desa/kelurahan.

Keterlibatan pengurus RTRW bukan sekedar sentuhan kearifan lokal namun juga menghidupkan kembali penyelenggaraan pemerintahan Desa khususnya dalam menghantarkan pelayanan publik yang prima kepada masyarakat.

Pelayanan pada jenjang Desa difasilitasi 18 Kasi Kecamatan yang ditunjang dengan pelayanan responsif oleh Dispendukcapil dengan mendekatkan pelayanan ke Masyarakat melalui sistem "jemput bola” dengan artian bahwa pelayanan diselenggarakan pada lokasi yang ditentukan seperti Desa/kecamatan dengan mendatangkan petugas dari Dispendukcapil. Hasil pelayanan jemput bola dientry oleh operator Dispendukcapil untuk dicetak sebagai KK yang telah termutakhirkan selanjutnya dilaksanakan alih media guna melindungi KK sebagai arsip yang tidak dapat dimusnahkan. Selain itu, dalam upaya meningkatkan pemahaman masyarakat maupun feedback yang diharapkan, Dispendukcapil meletakkan forum konsultasi publik Kakekku Datang secara on air pada media Radio Suara Giri sebagai sarana intensifikasi sosialisasi program Kakekku Datang.

Proses pelayanan sebagaimana dimaksud di atas juga terintegrasi dalam website Dispendukcapil yang ditunjang sistem informasi tool check NIK untuk mengecek NIK, KK dan Daftar Kakekku Datang yang memberikan informasi secara transparan tentang capaian pelayanan KK dan adminduk lainnya serta pemberitahuan via SMS kepada penduduk bersangkutan bila KK-nya telah selesai dicetak. Secara pendanaan, program Kakekku Datang mengkolaborasikan pelbagai sumber pendanaan memanfaatkan APBN, APBD, dan APBDesa.

Melalui Program Kakekku Datang, permasalahan Data Anomali dan Data Ganda dapat diselesaikan sekaligus berbasis pemutakhiran KK Count $\mathrm{O}$ yang notabene memuat data penduduk dalam skala keluarga paling komprehensif. Sejak titik awal penyelenggaraan Kakekku Datang pada bulan Mei t.a. 2015, program ini telah berhasil melakukan pemutakhiran bidota penduduk dalam KK sebanyak 9.846 KK. Sebuah pencapaian yang "hanya" mencapai $4 \%$ dari total KK Count 0 namun jauh melebihi ekspetasi mengingat 69,37\% biodata penduduk dalam KK seluruh Kabupaten Gresik tidak pernah beranjak dari fase stagnasi selama 6 tahun dari tahun 2008 s.d. 2014. Disisi lain, personil teknis pada tahun pertama penyelenggaraan Kakekku Datang 
juga masih sangat terbatas dengan 5 petugas entry KK reguler dan 8 tenaga alih media yang diperbantukan untuk mencover 1.332.972 Jiwa penduduk Kabupaten Gresik yang termuat dalam 369.120 KK.

Selain pemulihan data anomali dan data ganda sekaligus dalam pemuthakiran KK count 0 , Program kakekku datang juga menarik tuas akselerasi pelayanan akta kelahiran untuk penduduk usia 0-18 tahun yang ditargetkan dalam agenda pembangunan RPJMN mencapai $85 \%$ pada tahun 2019. Pada tahun 2015, penerbitan akta kelahiran untuk penduduk usia 0-18 tahun telah mencapai 58,12\%. Seluruh capaian ini merupakan ekspetasi dengan dimuatnya 5 (lima) paket pelayanan kakekku datang yang meliputi;

1. Pemutakhiran Data Count 0, Data Anomali, dan Data ganda;

2. Penghapusan Kematian melalui Paket Akta kematian dan KK;

3. Penerbitan Akta Kelahiran melalui Paket Akta Kelahiran dan KK;

4. Penambahan baru anggota Keluarga dalam KK akibat dinamika perpindahan; dan

5. Pemisahan KK.

Didukung keterlibatan RTRW, petugas register Desa, hingga Kecamatan yang ditunjang pelayanan jemput bola serta terintegrasi dengan sistem informasi yang dibangun dan media publikasi yang dipilih sebagaimana diuraikan sebelumnnya. Pelbagai substansi yang menjadikan program Kakekku Datang unik sehingga mampu memutakhirkan pelayanan kartu keluarga yaitu;

1. merupakan pemutakhiran biodata penduduk pertama di Kabupaten Gresik yang melibatkan pengurus RTRW dan petugas register Desa;

2. integrasi pendanaan yang melibatkan APBN dan APBD untuk memenuhi ketersediaan blangko KK dan operasional pelayanan dan pemanfaatan Alokasi Dana Desa untuk mendukung pelayanan adminduk di jenjang Desa;

3. sistem pelayanan Kakekku Datang terintegrasi melalui pelayanan responsif jemput bola, sistem informasi, media konsultasi publik secara on air, dan alih media tehadap KK yang telah dimutakhirkan.

4. satu program untuk menggapai pemecahan permasalahan yang kompleks dengan kesederhanaan paket pelayanan.

Melalui inovasi di atas, permasalahan kronis untuk mewujudkan tertib administrasi kependudukan telah mencapai progress yang signifikan. Sebagaimana dijelaskan bahwa keterlibatan pengurus RTRW hingga petugas register Desa telah berhasil memberikan progress perbaikan KK count 0 yang signifikan dibandingkan dengan pendataan ulang sebelumnya yang tidak efektif. Keterlibatan asset kearifan lokal Desa juga mengoptimalkan validasi data karena Kakekku Datang memberikan porsi bagi pengurus RTRW sebagai pamong terdepan dan terdekat dalam masyarakat 
untuk memverifikasi yang selanjutnya di re-check oleh Petugas Register Desa dan diteruskan oleh Kecamatan.

Berdasarkan pengalaman sebelumnya, pendanaan pelayanan pada jenjang Desa sulit dilaksanakan karena terkendala mekanisme maupun pemahaman aparatur pemerintahan Desa namun Kakekku Datang memanfaatkan momentum impelementasi UU Desa yang berimplikasi pada peningkatan alokasi anggaran Desa secara signifikan dengan meintegrasikan unsur pendanaan pelayanan di Desa (pengurus RTRW dan Petugas Register) melalui ADD.

Sistem pelayanan yang responsif terintegrasi dengan media publikasi yang "populer" untuk masyarakat Kabupaten Gresik serta dukungan system informasi yang informatif mengoptimalkan pelaksanaan Kakekku Datang sehingga memacu pencapaian pelayanan adminduk sebagaiman diuraikan, memberikan frekuensi feedback yang cukup tinggi dari masyarakat, dan memberikan informasi yang lebih detail maupun mudah dipahami bagi masyarakat umum. Selain itu, penyelenggaraan alih media terhadap KK yang telah dimutakhirkan telah memberikan solusi untuk melindungi arsip- arsip yang tidak dapat dimusnahkan.

Berikut kronologi pelaksanaan Kakekku Datang beserta rencana aksi yang telah dikembangkan:

\section{Distribusi KK Count 0}

Dalam rangka mengatasi permasalahan pokok yaitu Data Anomali dan Data Ganda serta meningkatkan atribusi pelayanan adminduk seperti pencatatan akta kelahiran maka dipilih KK yang tidak pernah dimutakhirkan sejak pertama kali diterbitkan pada tahun 2008 atau diaktegorikan Count 0. Pemutakhiran Biodata penduduk berbasis Count $\mathrm{O}$ dipilih mengingat komprehensifitas data yang dimuatnya mencakup identitas terlengkap penduduk dalam lingkup keluarga meliputi nama, NIK, jenis kelamin, tanggal lahir, agama, jenis pekerjaan, status perkawinan, status hubungan dalam keluarga, kewarganegaraan, hingga nama ayah dan ibu. Dalam pelaksanaan di lapangannya, Kategori KK count 0 diekstrak dari aplikasi SIAK oleh Bidang Informasi Dispendukcapil selanjutnya dikeluarkan oleh tim fungsional Adminsitration Data Base (ADB) yang ditunjuk oleh Kadispendukcapil. KK count 0 dicetak pada kertas putih persis seperti KK resmi sebanyak 256.047 KK kemudian diedarkan ke masing-masing Desa oleh Bidang Informasi Dispendukcapil. Catatan jumlah KK count 0 masing-masing direkapitulasi untuk diketahui Camat beserta instruksi pembaharuannya.

\section{Keterlibatan Pengurus RT RW dan Petugas Register Desa}

Merujuk pengalaman pemutakhiran KK pada Tahun 2011 yang dilakukan dengan cara coklit atau pencocokan dan penelitian. Metode coklit yang digunakan tidak melibatkan mata rantai proses seperti Kakekku Datang karena prosedur perubahan biodata dilterima secara lansung oleh petugas Dispendukcapil dari masyarakat bersangkutan. Dengan mekanisme ini ternyata dihasilkan data yang 
masih belum tervalidasi karena jenjang verifikasi belum dilaksanakan. Berdasarkan pengalaman ini, Kakekku Datang melibatkan pengurus RT RW sebanyak 8000 pengurus di bawah rentang kendali 356 petugas register desa/kelurahan yang difasilitasi oleh 18 Kasi di tingkat Kecamatan. Keterlibatan unsur penyelenggaraan pemerintahan Desa tersebut telah ditetapkan denganSurat Keputusan Kepala Dispendukcapil. Dalam proses pelaksanaannya, Pembaharuan KK Count 0 disampaikan kepada masyarakat melalui RTRW berikut form yang perlu diisi atau surat pernyataan perubahan biodata penduduk. Tahapan selanjutnya, Kakekku Datang memberikan porsi bagi pengurus RTRW untuk memverifikasi awal di tingkat Desa yang selanjutnya diklarifikasi oleh Petugas Register Desa. Hasil proses verifikasi di tingkat Desa dihimpun di Kecamatan untuk diserahkan ke Dispendukcapil.

Proses ini tidak dapat dimaknai "memanjangkan birokrasi" melihat

kenyataan di lapangan yang ternyata lebih memudahkan masyarakat untuk mengakses pelayanan mengingat RTRW adalah pamong yang terdekat

dengan masyarakat sehingga memudahkan interaksi masyarakat yang membutuhkan pelayanan maupun sekedar mencari informasi. Kedekatan secara sosiologis maupun demografis ini juga berhasil dimanfaatkan untuk meningkatkan kualitas validasi data kependudukan dengan proses verifikasi berjenjang. Porsi yang diberikan oleh Kakekku Datang ternyata juga berpengaruh positif pada dimensi lain seperti menghidupkan kembali penyelenggaraan pemerintahan di tingkat Desa khususnya pada aspek pelayanan kepada masyarakat, menggiatkan kembali wajib lapor 1x24 jam bagi tamu atau pendatang baru yang mampu menangkal potensi terorisme di lingkungan RTRW, serta menghadirkan jalur koordinasi yang harmonis mulai dari tingkat Desa, intermediary Kecamatan, hingga Daerah.

\section{Pelayanan Jemput Bola}

Dalam rangka akselerasi pelaksanaan program, Dispendukcapil menyelenggarakan pelayanan Jemput Bola di tengah masyarakat pada lokasi Desa dan/atau Kecamatan yang telah ditentukan.Selama tahun 2015, pelayanan jemput hanya dilakukan 20 kali akibat keterbatasan anggaran. Dalam pelaksanaannya, petugas yang terjun ke lapangan berjumlah 5 orang yang terdiri 2 orang dengan tupoksi memproses pelayanan akta kelahiran dan kematian, serta 3 orang bertugas untuk perekaman e-KTP dan pemutakhiran KK dengan jam pelayanan menyesuaikan jam kerja yaitu pada pukul 08.00 s.d. 15.30. Dengan keterbatasan anggaran dan personil pada tahun pertama pelaksanaannya ternyata program Kakekku Datang telah mendapatkan feedback yang postif dalam masyarakat, terintegrasi dengan pelayanan di tingkat Desa dan Kecamatan, program ini telah berhasil melakukan pemutakhiran bidota penduduk dalam KK sebanyak 9.846 KK.

4. Adapun paket pelayanan yang ditawarkan dalam pelayanan jemput bola meliputi Pemutakhiran Data Count 0, Data Anomali, dan Data ganda; Penghapusan Kematian melalui Paket 
Akta kematian dan KK; Penerbitan Akta Kelahiran melalui Paket Akta Kelahiran dan KK; Penambahan baru anggota Keluarga dalam KK akibat dinamika perpindahan; dan Pemisahan KK.

\section{Alih Media Arsip}

Hasil pemutakhiran KK sebagaimana dilalui dalam proses di atas selanjutnya dialihmediakan oleh 8 tenaga alih media yang diperbantukan. Proses alih media ini merupakan solusi untuk mengelola penataan arsip Dispendukcapil sekaligus melindungi produk pelayanan adminduk mengingat KK merupakan kategori arsip yang tidak dapat dimusnahkan.

6. Sosialisasi melalui Radio Suara Giri

Sebagai upaya intensifikasi sosialisasi program Kakekku Datang sekaligus menghadirkan forum konsultasi yang memudahkan interaksi antara Dispendukcapil dan masyarakat terkait program ini maka dipilihlah media sosialisasi secara on air melalui media Radio Suara Giri. Media ini mungkin tidak sepopuler media lainnya maupun stasiun radio lainnya namun merupakan alternatif yang "merakyat" mempertimbangkan jangkauan siaran yang mencakup seluruh desa dan tentu saja pendengar setia dari setiap kalangan masyarakat Kabupaten Gresik.Pada tahun 2015, dispendukcapil telah melaksanakan sosialisasi melalui Radio Suara Giri sebanyak 6 kali dengan menghadirkan Kepala Dispendukcapil.Sedangkan, format sosialisasi adalah memberikan pemahaman umum dan dialog interaktif.

7. Sistem infomasi penunjang Kakekku Datang

Selain radio suara giri, pamflet, ataupun konsultasi secara lansung melalui pelayanan jemput bola dan petugas di Desa maupun kecamatan, Masyarakat juga dapat mengakses informasi program Kakekku Datang pada official website Dispendukcapil serta memudahkan untuk mengecek NIK dan KK secara by name by adrees melalui tool check NIK. Pada perkembangannya, untuk KK yang telah dimutakhirkan dan telah berhasil dicetak,sistem informasi akan memberikan informasi secara lansung kepada penduduk bersangkutan bahwa pemutakhiran KK yang diajukan telah selesai dicetak via SMS.

\section{Kesimpulan}

Meskipun secara normatif telah terdapat pengaturan terkait dengan pemutakhiran Kartu Keluarga, namun ternyata dalam tatatan implentasinya dengan berbagai alasa sosiologis, hal tersebut sulit dilakukan. Maka dalam rangka menjawab permasalahan tersebut, maka lahirlah program Pelayanan Kakekku yang digagas oleh Pemerintah Kabupaten Gresik. Program Kakekku sebagai suatu terborsan dalam pemutakhiran Kartu Keluarga yang berhasil , karena selain terintegrasi dari satuan masyrakat paling kecil yaitu RTRW, sistem pelayanan Kakekku datang 
terintegrasi melalui pelayanan responsive yang bersifat jemput bola, sehingga dapat dijangkau dengan mudah oleh masyrakat

\section{Bibliography}

Buku

Ridwan, H.R. (2014). Hukum Administrasi Negara, RajaGrafindo Persada: Jakarta

Nurmayani. (2009). Hukum Administrasi Daerah. Universitas Lampung:

Bandarlampung.

Harbani Pasolong. (2010). Teori Administrasi Publik. Alfabeta: Bandung. Sampara Lukman .(2000).

Manajemen Kualitas Pelayanan. STIA LAN

Press: Jakarta.

Abdulkadir Muhammad. (2004) .Hukum dan Penelitian Hukum. Bandung:Citra Aditya Bakti 